\title{
Ecclesiological Tendencies in the Ecumenical Approach of the Council of Crete
}

\author{
Alexandru-Marius Crișan ${ }^{*}$
}

The Ecumenical legacy of the Council of Crete convened in 2016 is extremely important because of the consistent discussions on this topic during the grounding of the Council, but mostly subsequent to that, when the process of reception of the Council began. The Holy and Great Council of Crete of 2016, known also as the PanOrthodox Council, issued six official documents plus a Message and an Encyclical. Among those documents, one is dedicated to the question of ecumenical relations. Inside various Orthodox Autocephalous Churches different groups denounced the Council because of its ecumenical approach, meaning that a good understanding of the ecumenical legacy of the Council of Crete is one of the most important keys in its reception. In this study I will try to inspect the ecclesiological theology found in the Document on Ecumenical Relations released in 2016 by the Council of Crete, thereby analyzing why some of the groups rejected this document. Comparing different forms of the documents with the final approved form will help us understand how the Orthodox approach to ecumenism evolved in time, since the beginning of the preparations for the Holy and Great Council of the Orthodox Church.

Keywords: Council of Crete, Pan-Orthodox Council, Ecumenism, Ecclesiological Theology, Ecclesiological Ecumenism, Orthodox Ecumenism

\section{Introduction: Historical Background of the Pan-Orthodox Ecumenical Concern}

Carefully prepared during a long period of time ${ }^{1}$, the Council of Crete could have offered a unitary Orthodox point of view on the Ecumenical Movement and on the relations of the Orthodox Church with other Christian realities

\footnotetext{
* Dr. Alexandru-Marius Crișan, Research Fellow, Institute for Ecumenical Research, Lucian Blaga University of Sibiu, str. Mitropoliei 30, 550179, Sibiu, RO, alexandru13marius@ gmail.com.

${ }^{1}$ For a historical view on the matter see: Viorel Ioniță, Towards the Holy and Great Synod of the Orthodox Church. The Decisions of the Pan-Orthodox Meetings since 1923 until 2009, trans. Remus Rus, Basel, Friederich Reinhardt Verlag 2004; Theodoros A. Meimaris, The Holy and Great Council of the Orthodox Church \& the Ecumenical Movement, Thessaloniki, Ant. Stamoulis Publications 2013; Hilarion Alfeyev, "Le Saint et Grand Concile", in: Irénikon 84 (2-3/2011), p. 203-224; Noël Ruffieux, "The Preparation and Reception of the Council", in: St. Vladimir's Theological Quarterly 60 (1-2/2016), p. 11-32; Alexandru-Marius Crișan, "Le Saint et Grand Concile de l'Église Orthodoxe. Panorthodoxe? Préparation. Débat. Éclaircissements", in: Mikhtav 82 (2018), p. 7-33.
} 
for the first time, thus defining a clear and unitarian ecclesiology, and to be a guide both for internal and external Orthodox relations. The Protestant theologian Dagmar Heller underlines the need of an ecclesiological clarification in contemporary Orthodox theology, a task that should have been completed by the Holy and Great Council:

In the $20^{\text {th }}$ century, however, the necessity of a Pan-Orthodox Council became necessary not only because of closer relations with non-Orthodox churches, but also because of internal Orthodox developments such as the emergence of an Orthodox diaspora, which apart from the fundamental issues of jurisdiction also demanded an ecclesiological clarification of the meaning of the primacy of honor of the Ecumenical Patriarch. ${ }^{2}$

It is important to mention that the Council of Crete, also known as the Holy and Great Council of the Orthodox Church was the only Orthodox expression on Ecumenism since the pan-Orthodox participation in WCC (between 1968 - when the Serbian Orthodox Autocephalous Church joined and 1997 - when the Georgian and Bulgarian Orthodox Churches withdrew). "In a way predictable to many" ${ }^{3}$ just before the Council of Crete, four of the autocephalous Orthodox Churches canceled their presence at the Council: the Bulgarian Orthodox Church, the Georgian Orthodox Church, the Antiochian Patriarchate and the Russian Orthodox Church (Moscow Patriarchate). Some of the Churches invoked ecclesiological and theological reasons involving ecumenical aspects to be analyzed later in this text. Georgios Vlantis finds the main reason for the absence of these Churches in the new social context of the $21^{\text {st }}$ century regarding the close relation between State and Church ${ }^{4}$.

Ecumenism was one of the characteristics of the Council of Crete, from the very beginning of its preparation. The initial moment of the Council is considered by many researchers to be the Patriarchal and Synodical Encyclical of the Ecumenical Patriarch Joachim III of June 12, 19025; through this document the Orthodox Churches were called to convene and to discuss in a synodical way problems regarding the relations between the Orthodox au-

\footnotetext{
${ }^{2}$ See: Dagmar Heller, "The (Holy and Great) Council of the Orthodox Churches. An Ecumenical Perspective”, in: The Ecumenical Review 69 (/2017), p. 288-300, 290.

${ }^{3}$ Expression taken from: Cristoph D'Aloisio, "En attendant les fruits du Concile du Crète", in: Le Messager Orthodoxe 161 (2/2016), p. 3-10.

${ }^{4}$ See: Georgios Vlantis, "Das Heilige und Große Konzil der Orthodoxen Kirche und seine ökumenische Bedeutung", in: Dokumentation 34 (2018), p. 6-11.

${ }^{5}$ For example: Job Ghetcha, "The Holy and Great Council and the Question of Ecumenism", in: The Ecumenical Review 69 (2/2017), p. 274-287.
} 
tocephalous Churches and the relation of the Orthodox Church, in general, with the world. The call to define an ecumenical modus vivendi, a way of relating with the other Christian realities is very clear in the 1902 Encyclical:

It is, moreover, pleasing to God, and in accordance with the Gospel, to seek the mind of the most holy autocephalous Churches on the subject of our present and future relations with the two great growths of Christianity, viz. the Western Church and the Church of the Protestants. Of course, the union of them and of all who believe in Christ with us in the Orthodox faith is the pious and heart-felt desire of our Church and of all genuine Christians who stand firm in the evangelical doctrine of unity, and it is the subject of constant prayer and supplication. ${ }^{6}$

This calling to define an ecumenical approach and the terms of a Churchworld relation came "60 years prior to the Second Vatican Council and 46 years before the creation of the World Council of Churches" , an aspect that confirms the profoundness of the ecumenical conscience in the Orthodox Church. Even if events and institutions such as the First and Second World Wars, the World Council of Churches and the Second Vatican Council helped or influenced the shaping a certain ecumenical direction, the 1902 call for an ecumenical engagement, which later generated a document on ecumenical relations belonged to the Orthodox World and is not an external influence. When the editor of the Crete documents in the Italian language, Pietro Chiaranz, states Crete owes its ecumenical approach to the Second Vatican Council ${ }^{8}$, he is, at best, just half correct. The Ecumenical Patriarch, Joachim III, was able to understand and already predict in the 1902 Encyclical the theological debates that arose with the question of the ecumenical approach and the difficulty of finding an ecclesiological view acceptable to everyone:

...but at the same time we are not unaware that this pious desire comes up against the unbroken persistence of these Churches in doctrines on which, having taken their stand as on a base hardened by the passage of time, they seem quite disinclined to join a road to union, such as is pointed out by evangelical and historical truth; nor do they evince any readiness to do so, except on terms

\footnotetext{
${ }^{6}$ See: "Patriarchal and Synodical Encyclical of the Ecumenical Patriarchate of 1902", in: Gennadios Limouris, Orthodox Visions on Ecumenism, Geneva, WCC Publications 1994, p. 2-3.

7 J. Ghetcha, "The Holy and Great Council”, p. 274.

${ }^{8}$ Pietro Chiaranz (ed.), La contestazione ignorata. La critica ortodossa al Concilio di Creta in quattro significativi documenti, Venice, Youcanprintit 2017, p. 4.
} 
and bases on which the desired dogmatic unity and fellowship is unacceptable to us. ${ }^{9}$

Another important moment was the promulgation in 1920 of the Synodical Encyclical "Unto the Churches of Christ Everywhere" considered by some to be "the culminating point of the Ecumenical Patriarchate attempts to rekindle the vision of Christian Unity" ${ }^{10}$. This Encyclical was "a calling to all Christian Churches for common action in order to form a League (koinonia) against the social evils, with an ultimate goal to achieve one day complete Christian unity". ${ }^{11}$ In 2013 Theodoros Meimaris questioned the term League used above if it did in 1920 "imply an ecclesial recognition of the non-Orthodox Churches". ${ }^{12}$ The Ecumenical Patriarch Athenagoras kept the idea of the Council alive after the two world wars, through two Patriarchal Letters addressed to the Primates of the Orthodox Churches in 1951 and 1952.

The concrete story of the Document on the Ecumenical Relations "actually began with the texts on Ecumenism adopted in 1971 during the first meeting of the Inter-Orthodox Preparatory Commission" ${ }^{13}$ In 1986 the Third Preconciliar Pan-Orthodox Conference was convened and it adopted, among other documents, "two texts on Ecumenism that actually modified the texts from 1971, which were no longer current (after 25 years)" ${ }^{14}$ Viorel Ioniță, the Romanian historian of the Council, who attended many of the preparatory meetings, observed that the 1986 Conference, which adopted and modified the texts on ecumenism was attended by some Hierarchs that later became Primates of their Autocephalous Orthodox Churches. ${ }^{15}$ This is

\footnotetext{
9 See: "Patriarchal and Synodical Encyclical", p. 3.

${ }^{10}$ Theodoros A. Meimaris, The Holy and Great Council, p. 30.

${ }^{11}$ Ibidem.

${ }^{12}$ Ibidem.

${ }^{13}$ A.-M. Crișan, "La lotta per le parole: Chiesa e Chiese nel documento sull'ecumenismo del Concilio di Creta", in: Apulia Theologica. Rivista della Facoltà Teologica Pugliese 5 (2/2019), p. 383.

${ }^{14}$ H. Alfeyev, "Le Saint et Grand Concile", p. 221; see also the two texts adopted in 1986, in English translation in: V. Ioniță, Towards the Holy and Great Synod, p. 167-170: "The Orthodox Church and the Ecumenical Movement", p. 170-176: "Relations of the Orthodox Church with the Christian World".

15 The examples mentioned by Ioniță: Metropolitan Bartholomew of Philadelphia, elected Ecumenical Patriarch in 1991; Metropolitan Parthenios of Cartage, Patriarch of Alexandria in 1987; Metropolitan Chrysostomos of Paphos, Archbishop of the Church of Cyprus in 2006; Metropolitan Chrystodoulos of Dimitrias, Archbishop of the Church of Greece in 1988; Bishop Nicholas of Presov, Metropolitan of the Orthodox Church of the Czech Lands and Slovakia in 1999. The Ecumenical Patriarch Bartholomew and the Archbishop Crysostomos of Cyprus are still in their office, representing a generation engaged in seeking the Christian unity. See: V. Ioniță, Towards the Holy and Great Synod, p. 86.
} 
key information in understanding the ecumenical engagement of some local autocephalous Orthodox Churches in the last years.

In 2014 a Synaxis of the Primates of the Orthodox Autocephalous Churches took place and the Ecumenical Patriarch announced the intention to convoke the long-awaited Council, "despite the existence of significant tensions between some Autocephalous Churches". ${ }^{16}$ The texts of the two documents on Ecumenism, prepared in 1986, were brought into discussion again in 2015 at the First meeting of the Special Inter-Orthodox Commission for the Preparation of the Council during the presidency of Metropolitan Ioannis Zizioulas. The representatives at this reunion decided on the combination of the two documents on Ecumenism. The decision was approved later that same year during the Fifth Pan-Orthodox Preparatory Conference held in Chambésy.

In June 2016, during the Council, the document was discussed on June 23rd, 24th and $25^{\text {th }}$, eventually being approved by the Council Fathers.

In what follows we will analyze some more theological aspects (Orthodox ecclesiological self-awareness related to ecumenism, the reception of other Christian Communities, the ecclesiological approach to WCC) as an attempt to reconstruct the ecclesiological approach of the document entitled Relations of the Orthodox Church with the Rest of the Christian World. ${ }^{17}$ Every mentioned aspect will be approached chronologically, as they were altered in different or successive preparatory meetings; this is why the important meetings where the document on ecumenical relations was considered (1971, 1986, 2015, 2016) will be mentioned more times, for every theological aspect addressed.

\section{The First Step: An Ecclesiological Orthodox Self-Understanding Related to the Ecumenical Movement}

\subsection{The Title}

During the 1986 Third Panorthodox Pre-conciliar Conference, discussing the relations of the Orthodox Church with the rest of the Christian World, the participants observed that the ecumenical approach of the future document would be dependent on a profound self-understanding. During this meeting, the future Primate of the Greek Orthodox Church, then Metropolitan Christodulos of Dimitrias, expressed the need for a thoroughly understood ecclesiology before initiating an ecumenical dialogue or trying to define other Churches. He presented to the audience a clear task to define: “...the

\footnotetext{
${ }^{16}$ G. Vlantis, "Das Heilige und Große Konzil”, p. 6.

${ }^{17}$ Referred in this study as: "the Document" or "the Document on ecumenical relations".
} 
Orthodox Church? What are we? That's what we have to say before asking ourselves who are the others" ${ }^{18}$. This kind of approach encourages us to trace a double direction in the Document on Ecumenical Relations: ad-extram for the dialogue with the others but also ad-intram which in 1986, according to the Metropolitan, seemed to be insufficiently explored and expressed.

This aspect had already been faced when the members of the Third Panorthodox Pre-conciliar Conference (1986) changed the title: Relations of the Orthodox Churches with the Rest of the Christian World to Relations of the Orthodox Church with the Rest of the Christian World. A tiny modification with an enormous ecclesiological significance. During the 1986 Conference the well-known Metropolitan Damaskinos of Switzerland ${ }^{19}$ further encouraged the alteration of the title. His explanation, as we can observe in the Proces verbaux, was very short but it had a profound dogmatic understanding. The use of the singular form of the word Church (Relations of the Orthodox Church) instead of plural form Churches favors two essential factors: an accurate ecclesiological understanding (weakened by the different historical and political factors of the $20^{\text {th }}$, or previous centuries) and the avoidance of misunderstandings that could appear when the Autocephalous Churches dialogued separately with different Christian realities. This decision was not an easy one since "the relations between Orthodox Churches were seriously affected from back then until today by nationalistic approaches". ${ }^{20}$

With this decision, the Orthodox world, divided in many administrative aspects, gave primacy to its "unique theological and ecclesiological aspect of the Church, and not to its local multi-administrative order" when approaching ecumenical questions. The existence of a unique commission for ecumenical dialogue for all Orthodox jurisdictions answered the need of having a common vision when it comes to external relations, resolving both a theological-ecclesiological aspect but also a practical one. ${ }^{21}$ The Orthodox

\footnotetext{
${ }^{18}$ See: Synodica X, IIIe Conférence Panorthodoxe Préconciliaire. 28 octobre - 6 novembre 1986. Procès verbaux - Documents, Secretariat pour la Preparation du Saint et Grand Concile de l'Eglise Orthodoxe (ed.), Genève, Les éditions du Centre Orthodoxe 2014, p. 105. The original text reported from Synodica is in French, for space and coherence reasons I quote directly my own English translation. This applies for all the Synodica quotations that will follow.

${ }^{19}$ Damaskinos Papandeou (1936-2011) was the president of various preparatory and ecumenical meetings in its quality of Metropolitan of Switerland representing the Ecumenical Patriarchate.

${ }^{20}$ G. Vlantis, "Das Heilige und Große Konzil”, p. 6.

${ }^{21}$ Already in 1968, during the Fourth Pan-Orthodox Conference it was stated in the Decisions: "From now on, no separate theological discussion should be held between any of the heterodox confessions and a particular local Orthodox Church with the purpose of achieving a certain agreement, and no contacts of other nature between the heterodox theologians and representatives of the local Orthodox Churches should be overlooked, and the
} 
commission, composed of members of all Orthodox jurisdictions under the presidency of a representative of the Ecumenical Patriarchate, was in this way an equal partner for the Catholic Church, an international ecclesiastical reality with a clear, unique administration able to set up instantly a Commission competent to represent all the Catholic reality. ${ }^{22}$ This fact confirms the strong dogmatic aspect of the document's title: using the singular instead of the plural form in the title meant, despite a certain ecclesiological understanding of the Church universality, a unitary way of acting in Ecumenical relations.

\subsection{The Introduction of the Document}

The introduction, having an obvious dogmatic composition, also tries to answer the need of ecclesiological self-understanding of the Orthodox Church. The document begins with a very clear confession: "The Orthodox Church is the One, Holy, Catholic and Apostolic Church". ${ }^{23}$

First of all, regarding the first paragraph of the Document we have to admit that it contains a clear ecclesiological confession and a clear theological direction: the Orthodox Church is the Church. With this theological ecclesiology, according to which there is a unique true Church (namely the Orthodox One), the document should be acceptable to everyone, even to the most traditional circles of the Orthodox Church. But the document was criticized even during its conception. Metropolitan Job Ghetcha, stated, before the convening of the Council, that the most controversial document is the one referring to the ecumenical relations and insisted on mentioning its ecclesiology: "it is essential, in order to understand the spirit of the document and to respond to the critiques that it has generated, to underline that the document identifies the Orthodox Church as the One, Holy, Catholic and Apostolic Church". ${ }^{24}$ As we shall see further, especially from the arguments of

whole content of such partial contacts be conveyed to the specific commission for information"; see: V. Ioniță, Towards the Holy and Great Synod, p. 145.

${ }^{22}$ See the fruitful Dialogue between the Orthodox Church (as a whole) and the Catholic Church (All the texts are available on: http://www.vatican.va/roman_curia/pontifical_councils/ chrstuni/sub-index/index_orthodox-ch.htm, viewed on March 2, 2020) between 1982 and 2016. After the Proclamation of the Autocephaly of the Ukrainian Church in January 2019 by the Ecumenical Patriarchate, the Moscow Patriarchate doesn't accept to participate anymore in the common dialogue of the Orthodox Church (as a whole).

${ }^{23}$ The very first paragraphs: "The Orthodox Church, as the One, Holy, Catholic, and Apostolic Church, in her profound ecclesiastical self-consciousness, believes unflinchingly that she occupies a central place in the matter of the promotion of Christian unity in the world today"; see the document: Relations of the Orthodox Church with the rest of the Christian World, available on the official website of the Holy and Great Council: https://www.holycouncil.org/-/rest-of-christian-world, viewed on March 20, 2020.

${ }^{24}$ See: J. Ghetcha, “The Holy and Great Council”, p. 275. 
those who challenged the theology contained in the document, a question seemed to have remained unanswered, at that moment, and even after 2016, namely: the fact that it is stated that the Orthodox Church is the Church obstructs any ecclesiological recognition for other Christian communities? This doubt constituted the base for the debate and even some limited rejection of the Crete document on ecumenical relations.

According to Thomas Németh, there is a lack of this strong Orthodox self-awareness in the Encyclical of the Holy and Great Council; "in the Encyclical, the Orthodox Church avoided, according to him, an exclusive identification with the Church of Christ" ${ }^{25}$ But this view has no foundation since the clear ecclesiological confession is present at the very beginning of the Document on ecumenical relations.

\section{The Reception of Other Christian Realities by the Document on Ecumenical Relations of Crete}

The doubt mentioned above refers to another phrase, "particularly interesting from the perspective of the non-Orthodox", ${ }^{26}$ that couldn't be accepted by the traditional circles: namely, the sixth paragraph, which tries to refer to other Christian confessions. The sixth paragraph of the final form of the document on the Ecumenical Relations states that:

In accordance with the ontological nature of the Church, her unity can never be perturbed. In spite of this, the Orthodox Church accepts the historical name of other non-Orthodox Christian Churches and Confessions that are not in communion with her, and believes that her relations with them should be based on the most speedy and objective clarification possible of the whole ecclesiological question, and most especially of their more general teachings on sacraments, grace, priesthood, and apostolic succession. ${ }^{27}$

The use of the word Churches for non-Orthodox Communities raised many discussions and debates in the Orthodox Church before and after the final signing of the Crete Document on Ecumenism. Răzvan Perșa considers this paragraph to be "the most controversial phrase of the Holy and Great

\footnotetext{
25 Thomas Mark Németh, "Das orthodoxe Konzil von Kreta. Offene Fragen und Perspektiven”, in: Jürgen Bründl, Florian Klug (eds.), Zentrum und Peripherie. Theologische Perspektiven auf Kirche und Gesellschaft. Festschrift für Otmar Meuffels, Bamberger Theologische Studien 38, Bamberg, Bamberg University Press 2017, p. 333.

${ }^{26}$ D. Heller, "The (Holy and Great) Council", p. 295.

${ }^{27} 6^{\text {th }}$ paragraph of the Relations of the Orthodox Church with the rest of the Christian World; see: https://www.holycouncil.org/-/rest-of-christian-world, viewed on March 20, 2020.
} 
Council". ${ }^{28}$ Many fundamentalist circles of the Orthodox Church have protested against this formulation, namely against the use of the word Churches for non-Orthodox.

For the first time this expression appeared during the First InterOrthodox Preparatory Commission held in Chambésy in 1971 in the Document-project on the Ecclesiastical Economy (theme prepared at that time by the Romanian Orthodox Church), at the end of which was stated that "our Orthodox Church (...) recognizes - even if it is the One, Holy, Catholic and Apostolic Church - the ontological existence of all these Churches and Christian Confessions". ${ }^{29}$

It is observable that from the very beginning the formulation, at least at the first view, left space for two ecclesiological directions. Most probably, this aspect was observed in 1971 by the authors themselves, who felt the need to put forward the "recognition of all these Churches and Christian Confessions" the expression: "even if it is the One, Holy, Catholic and Apostolic Church". Later, it seemed that such expressions as "ontological existence" or "all these Churches and Christian Confessions" were regarded as putting in danger the traditional ecclesiological direction of the future Document on Ecumenical Relations.

In 1986, during the Third Panorthodox Pre-conciliar Conference debates, the need for a ecclesiological clarification was revealed. Metropolitan Parthenius of Cartagine had a very imaginative intervention and asked what exactly is or is not recognized outside the official limits of the Orthodox Church:

...do I recognize that they constitute a Church or not? This is an important question. It's about mentioning what these men actually are. Is the Orthodox Church the only Church and all the others outside the Church? Or do they also hold something of the Church? What are Roman Catholics and what are the ancient Eastern Churches? If I admit that these are churches, I will at least start talking to them in a more fraternal way. ${ }^{30}$

In the reported text, the then Metropolitan Parthenius actually asked, in other words, what kind of ecclesiology must be in use: "Is the Orthodox Church the only Church and all the others outside the Church?" or do other

\footnotetext{
${ }^{28}$ See: Răzvan Perșa, "A canonical Analysis of the most controversial Phrase of the Holy and Great Council: «The Orthodox Church accepts the historical name of other non-orthodox Christian Churches and Confessions that are not in communion with her»", in: SUBBTO 62 (1/2017), p. 131-157.

${ }^{29}$ See: "Iconomia bisericească", in: Ortodoxia 24 (2/1972), p. 294.

${ }^{30}$ Synodica X, p. 102.
} 
Churches or Confessions "hold something of the Church?". In these expressions pronounced by the Alexandrinian Metropolitan we already observe clearly the tension between two ecclesiologies separated by the question of the boundaries of the Church. Professor Galitis (Athens University, in 1986 representant of the Greek Orthodox Church) wanted to open the discussion about the limits or boundaries of the Church: are the administrative boundaries identical with the spiritual boundaries of the Church? This unopened discussion left a space of interpretation both in the past and the present forms of the document. A clear mention of the boundaries of the Church wouldn't have allowed discussions on different ecclesiological directions in the Crete document on ecumenical relations. "Is everyone outside?" - an exclusive traditional ecclesiology or "somebody holds something of the Church?" - a more inclusive ecclesiology. While the Metropolitan of the Orthodox Church of Alexandria left an open discussion, Metropolitan Christodoulos of Dimitrias replied by giving a name to the two ecclesiologies and opting to pursue a traditional total exclusive ecclesiology:

Your Eminence, the Metropolitan of Carthage introduced into the discussion a major problem, that of the way we must consider Churches and Christian confessions situated outside our limits and with which we dialogue. If we do not solve this problem, I believe that we are struggling in vain (...). The question of His Eminence, the Metropolitan of Carthage, brought into discussion-I say it with much reserve - is what is known as the theory of branches. Will we accept this theory or remain at the unam sanctam? ${ }^{31}$

The two ecclesiologies mentioned by the future Primate of Greece are the unam sanctam ${ }^{32}$ and the branches theory. ${ }^{33}$ An attentive look at the meaning of the branches ecclesiology (a total inclusiveness of everyone) demonstrates

\footnotetext{
${ }^{31}$ Ibidem, p. 103-104.

32 The name very clearly comes from one of the last verses of the Latin version of the Nicene Creed: "Et unam, sanctam, catholicam et apostolicam Ecclesiam". Through this name the Metropolitan Christodoulos wanted to express an exclusive ecclesiology regarded as being traditional.

${ }^{33}$ The Branches Ecclesiology/Theory is "an ecclesiological proposition within Anglicanism and Protestantism that the One, Holy, Catholic and Apostolic Church includes various Christian denominations not necessary in formal communion. Some Anglican proponents of the theory usually only include the Roman-Catholic, the Eastern Orthodox and the Anglican Communion Churches, while the others also include the Oriental Orthodox, Church of East, Old Catholic and Lutheran Churches. The theory is often incorporated into the Protestant notion of the Invisible Church, a structure binding all Churches together"; see: Claude Beaufort, The Christian Faith: An Introduction to Dogmatic Theology, New York, SPCK 1943, p. 279.
} 
that what Metropolitan Christodoulos identified as branches theory is not what Metropolitan Parthenius intended to express with the words "holds something of the Church". Those words ("hold something of the Church") open the document to the reception of "elements" of ecclesiality from other Christian realities, which would not be considered equal to the Orthodox Church. This is totally different from the branches theory. Actually, the ecclesiological approach proposed by Metropolitan Parthenius is not so alien to the Patristic heritage or even to modern Orthodox theology. The $95^{\text {th }}$ Canon of Trullan or the $1^{\text {st }}$ Canon of Saint Basil describe different ways of receiving heterodox to the Orthodox faith, depending on the heresy professed. George Florovsky, following the footsteps of Augustine, writes about the valid sacraments even in Schism, nonetheless the union with the Church is not perfect. ${ }^{34} \mathrm{He}$ also mentions the praxis of the Moscow Patriarchate to receive Catholic priests who want to convert to Orthodoxy, without re-ordination, just through Confession, a practice inherited from Petru Movilă himself. ${ }^{35}$ The Romanian theologian Dumitru Stăniloae also wrote about this issue as far back as $1931,{ }^{36}$ suggesting three ways of receiving schismatics and heretics into the Orthodox Church: solely Confession (Catholics), through Chrism (Protestants) or Baptism (Anti-Trinitarian heretics or not-baptized). ${ }^{37}$ Later, in the second volume of his major work The Dogmatic Theology, Stăniloae referred to other Churches as Imperfect Churches. ${ }^{38}$ Metropolitan John Zizioulas also speaks about the fact one can still use the word Church for some schismatic communities because of the validity of the Baptism. ${ }^{39}$ All these examples, ancient or modern, could easily be summarized by Metropolitan Parthenius's question: "do they hold something of the Church?"

The doubts whether the document could express the theory of the branches are the reason for all the modifications performed on the phrase "the Orthodox Church recognizes the ontological existence of all these Churches and Confessions". Earlier in 1986, during the same Third Panorthodox Preconciliar Conference, Professor Theodor Zizis, later to be a key-person for

\footnotetext{
${ }^{34}$ George Florovsky, "The Boundaries of the Church", in: The Collected Works, vol. 13, Ecumenism I: A Doctrinal Approach, Vaduz, Büchervertriebsansalt 1989, p. 42.

${ }^{35}$ Ibidem.

${ }^{36}$ Dumitru Stăniloae, "Cari dintre eretici şi schismatici vor putea fi primiţi în sânul Bisericii Ortodoxe: a. Prin botez, b. Prin mirungere, c. Prin libelos pisteos?”, in: Revista Teologică 21 (11-12/1931), p. 444-447.

${ }^{37}$ D. Stăniloae, "Care dintre eretici”, p. 447.

${ }^{38}$ D. Stăniloae, Teologie Dogmatică Ortodoxă, vol. 2, Bucharest, Editura Institutului Biblic și de Misiune al Bisericii Ortodoxe Române 2003³, p. 275.

${ }^{39}$ John Zizioulas, "Orthodox Ecclesiology and the Ecumenical Movement", in: Sourozh Diocesan Magazine 25 (1985), p. 23.
} 
the opposition to the Council of Crete proposed an alteration to enforce the nuance of a traditional ecclesiology in the phrase mentioned:

$\ldots$ it is a matter of recognizing the "ontological existence" of the other Christian Churches. There is the contradiction. We can recognize the "existence", but not the "ontological existence" of the other Christian Churches. Below, we are talking about: "clarification ... of the ecclesiological question". I propose to complete "clarification from their part..." to avoid any misinterpretation and misunderstanding. ${ }^{40}$

A solution acceptable to Professor Zizis in 1986 was found by a common discussion group of which he was also part. The intention to modify the paragraph was suggested to the assembly by Bishop Jeremiah of Wroclaw, who suggested replacing ontological existence with real existence, ${ }^{41}$ the proposal was accepted.

Uncertainty regarding the ecclesiological spirit of the document persisted, as in 2001 Metropolitan Hilarion Alfeyev was writing that the document needed a fundamental/general review, with a clear reference to its ecclesiological direction.

During the Fifth Panorthodox Pre-conciliar Conference held in 2015, the formulation regarding the recognition of other Churches and Christian Confessions from the document on ecumenical relations was again discussed and modified: the words "the existence de facto" were replaced by "historical existence". There is also another alteration performed in 2015: the formulation "all the Churches and Christian Confessions" was replaced by "other Churches and Christian Confessions". 42 During the Fifth Pan-Orthodox Preparatory Conference in 2015 all the delegations, representing the 14 Autocephalous Churches, signed the document referring to the ecumenical relations. It is clear that these alterations meant to enforce a traditional ecclesiological direction. Erasing the expression "all these Churches" leaves no space for branches ecclesiology but still, the words other Churches could open a certain type of reception of other Christian realities.

One of the most significative contesters of the document on ecumenical relations, right before the gathering of the Holy and Great Council in Crete, was the Church of Georgia. Through its communiqué, the Georgian Orthodox Church stated, referring to the Document on the Ecumenical Relations, that it "contains ecclesiological and terminological errors and requires serious alterations. If the alterations are not made, the Church of

\footnotetext{
${ }^{40}$ See: Synodica X, p. 231.

${ }^{41}$ Ibidem.

${ }^{42}$ V. Ioniță, Towards the Holy and Great Synod, p. 163.
} 
Georgia will not sign the text". ${ }^{43}$ This statement doesn't mention explicitly where exactly the "ecclesiological and terminological errors" are, but it is clear that the declaration refers to the sixth paragraph regarding the recognition of other Churches. The Document on Ecumenical Relations was altered further until the Council of Crete, and as a result, the Church of Georgia didn't attend.

The Document entitled "Relations of the Orthodox Church with the rest of the Christian World" was under debate during the Council, being taken into discussion on June 23, 24 and 25. As of this writing the Minutes of the Council are still classified; still, some information beyond the official Statements can be found because of a Council Diary ${ }^{44}$ published soon after the Council of Crete by one of the bishops who attended the event: Bishop Maxim Vasilijevic (a member of the delegation of the Serbian Orthodox Church). The author of this Diary dedicated some pages to the debates risen around the Document on Ecumenical Relations, thus offering some valuable information, agreeing that ecumenism "represents the main problem placed before the Council fathers" and "the use of the word Church for the heterodox". ${ }^{45}$

Reading the pages of the Council's Diary, one can understand how important and difficult this theme was, not only for the internal conciliar debate but also for some local Churches. At some point Bishop Maxim even writes that a Serbexit ${ }^{46}$ from the Council could have happened. In one of his speeches Bishop Atanasije $e^{47}$ "stated that the document should not be rejected; nonetheless, a better title and a better ecclesiological foundation would be more suitable". ${ }^{48}$ Even if Bishop Atanasije is to be seen in favour of the document, his proposal to change "the rest of the Christian World to Heterodox" is minimalist and has a tendency towards an ecclesiology which divides the Christian reality in two: the Orthodox on one side and all the others on the other side; in other words the same total ecclesiological exclusiveness wanted by Christodoulos in 1986. In his Diary, Bishop Maxim dedicates some pages to showing that the approach of the Document in naming

\footnotetext{
${ }^{43}$ See: the Communiqué on the Georgian Patriarchate website: http://patriarchate.ge/geo/ wminda-sinodis-sxdomis-oqmi-25/ (in Georgian) or an English translation available on the Romanian Patriarchate website: https://basilica.ro/en/georgian-orthodox-church-communique-on-the-holy-and-great-council/, viewed on March24, 2020.

${ }^{44}$ Maxim Vasiljevic, The Diary of a Council. Reflections from the Holy and Great Council at the Orthodox Academy in Crete. June 17-26, 2016, Los Angeles, Sebastian Press 2016.

${ }^{45}$ M. Vasiljevic, The Diary, p. 40.

${ }^{46}$ Ibidem.

${ }^{47}$ Bishop Atanasije of Bihac' and Petrovaci.

${ }^{48}$ M. Vasiljevic, The Diary, p. 40.
} 
some other Christian Confessions Churches for historical reasons is correct and faithful to the "Fathers of the Ancient Church". 49

But the main actor regarding this formulation of the document on the Ecumenical Relations was the Church of Greece, which during the Council debates, managed to impose another alteration to the nuance of the phrase towards an ecclesiology of clearer traditional and exclusivist nature. The suggestion was well received and lead to the signing of the document by all the delegations present at the Council. The document was in this way modified again and so the consensus was reached. The $6^{\text {th }}$ paragraph's text was changed from "The Orthodox Church acknowledges the historical existence" to "The Orthodox Church accepts the historical name". ${ }^{50}$

A summary look at this document's history revealed that actually, whenever the document regarding the Ecumenical Relations was taken into discussion, the formulation referring to other Churches was changed because, according to some of the Council's participants, this phrase could have led to the acceptance of the branches ecclesiology. Radu Bordeianu courageously steps forward and mentions that through all the alterations applied, from an ecumenical point of view, "the document The Relations of the Orthodox Church with the Rest of the Christian World took some steps backward". ${ }^{51}$ More and more traditional expressions were chosen, "which were meant to appease ultraconservative concerns but in the end satisfied no one" ${ }^{52}$ The possibility of confessing even without intending the ecclesiology of the branches had to be avoided at any cost:

\footnotetext{
49 "Sources from almost half of Migne's Patrology, as well as those after the fall of Constantinople, give a clear and unequivocal witness. Even though it is (mistakenly) thought that St. Mark of Ephesus referred to the Roman Catholic church as a Church only until the Council in Florence and that after the Council he did not, things are actually different. Namely, after the Council of Florence both Mark and the entire Eastern Church steadily referred to the Roman Catholic church as a Church. St. Mark of Ephesus (e.g., the Encyclical Letter of St. Mark of Ephesus in 1440) says it in such a way that he does not even think it does not refer to a Church. There are other examples. (...) the canonist Theodore Balsamon, Patriarch of Antioch, (...) refers to the Roman Church as a Church. (...) the great anti-Latin, Gennadius Scholarius, had a similar position. (...) What happened after the Council of Florence? The Orthodox Church reacted to that Council in 1484 with the Council in Constantinople, which determined the manner of accepting those who convert from the Latin faith to the Orthodox. The decision states: only with chrismation, not baptism. We notice that this was the Council that rejected the Florentine union. We don't find any reaction afterwards which might change the use of the term "Church." (...)"; see: Ibidem, p. 40-41.

${ }^{50}$ See: Ibidem, p. 46.

${ }^{51}$ Radu Bordeianu, "Getting from Conflict to Communion. Ecclesiology at the Center of Recent Lutheran-Orthodox Dialogues and the 2016 Orthodox Council of Crete", in: Worship 91 (2017), p. 521.

${ }^{52}$ Ibidem.
} 
Alexandru-Marius Crișan

\begin{tabular}{|l|l|l|l|}
\hline $\begin{array}{l}\text { 1971: First } \\
\text { Inter-Orthodox } \\
\begin{array}{l}\text { Preparatory } \\
\text { Commission }\end{array}\end{array}$ & $\begin{array}{l}\text { 1986: Third } \\
\text { Preconciliar } \\
\text { Panorthodox } \\
\text { Conference }\end{array}$ & $\begin{array}{l}\text { 2015: Fifth } \\
\text { Preconciliar } \\
\text { Panorthodox } \\
\text { Conference }\end{array}$ & $\begin{array}{l}\text { 2016: Final version } \\
\text { signed during the } \\
\text { Council of Crete }\end{array}$ \\
\hline $\begin{array}{l}\text { The Orthodox } \\
\text { Church recognizes } \\
\text { the ontological } \\
\text { these Christian } \\
\text { Churches and } \\
\text { Confessions }\end{array}$ & $\begin{array}{l}\text { The Orthodox } \\
\text { Church recognizes } \\
\text { the existence } \\
\text { de facto of the } \\
\text { Christian Churches } \\
\text { and Confessions }{ }^{54} .\end{array}$ & $\begin{array}{l}\text { The Orthodox } \\
\text { Church acknow- } \\
\text { ledges the historical } \\
\text { existence of other } \\
\text { Christian Churches } \\
\text { and Confessions } \\
\text { that are not in } \\
\text { communion with } \\
\text { her }\end{array}$ & $\begin{array}{l}\text { The Orthodox } \\
\text { Church accepts } \\
\text { the historical } \\
\text { name of other } \\
\text { non-Orthodox } \\
\text { Christian Churches } \\
\text { and Confessions } \\
\text { that are not in } \\
\text { communion with } \\
\text { her }\end{array}$ \\
\hline
\end{tabular}

We mentioned three ecclesiologies taken into consideration by participants who attended the preparation or the Council: the total exclusive and conservative Unam Sanctam (named like this according to Metropolitan Christodoulos's words), the total inclusive branches theory and a middle one: a reception at different levels of ecclesiology (inspired by the words of Metropolitan Parthenius from 1986: "do they hold something of the Church?"). It is clear that every alteration wanted to make a conservative ecclesiology clear in an exclusive direction in order to make the document more acceptable to fundamentalist groups. But traces of an ecclesiology that implies a possible reception on different ecclesiological levels of the non-Orthodox realities can still be found. It is obvious what exactly this statement from the final form of the Document on ecumenical relations does not mean: it does not express a totally ecclesiological inclusiveness; it is more difficult to understand what lies positively behind the statement especially with the use of the verb "accepts" and the expression "historical name". Georgios Vlantis thinks that through the formulations mentioned above, "the Orthodox Church wanted to express its respect for the other Churches' self-awareness, but in the meantime, to deny any ecclesiological status of

\footnotetext{
53 See: "Iconomia bisericească", p. 294.

${ }^{54}$ See the 1986 document: Relations of the Orthodox Church with the Christian World, in: V. Ioniță, Towards the Holy and Great Synod, p. 171.

55 The Pre-conciliar Document: Relations of the Orthodox Church with the Christian World, see: https://www.holycouncil.org/-/preconciliar-relations, viewed on April 30, 2020 www. holycouncil.org/preconciliar.

${ }^{56}$ The Document Relations of the Orthodox Church with the Rest of the Christian World. see: https://www.holycouncil.org/-/rest-of-christian-world, viewed on April 30, 2020.
} 
these other Christian Churches and Confessions". ${ }^{57}$ It is not clear whether it only refers to churches that have grown historically, or to the many new congregations that also see themselves as churches. The same ecumenical and ecclesiological direction is to be found also in the Encyclical of the Holy and Great Council of the Orthodox Church which underlines the need of "witnessing in dialogue" and "the development of brotherhood to promote the peace", ${ }^{58}$ but without "compromises in matters of faith". ${ }^{59}$

After mentioning that "the Orthodox Church accepts the historical name of other non-Orthodox Churches and Confessions", theological concepts regarding the ecclesiology are mentioned. Actually, these concepts are the same as those mentioned in the beginning of the document, when the nature of the Orthodox Church is described. This could be a clue towards an ecclesiology of an ecumenical reception at different levels: a non-Orthodox reality could be more or less Orthodox, depending on the theological and ecclesiological aspects fulfilled by the respective non-Orthodox confession. In the meantime, the mention of these theological concepts highlights "the relevance of the ecclesiology for the ecumenism". ${ }^{60}$

\begin{tabular}{|l|l|}
\hline $\begin{array}{l}\text { II }{ }^{\text {nd }} \text { paragraph of the Document, } \\
\text { referring to Orthodox } \\
\text { self-understanding }\end{array}$ & $\begin{array}{l}\mathrm{VI}^{\text {th }} \text { paragraph of the Document, referring } \\
\text { to ecumenical understanding }\end{array}$ \\
\hline $\begin{array}{l}\text { The Orthodox Church founds the unity } \\
\text { of the Church on its establishment } \\
\text { by our Lord Jesus Christ, and on the } \\
\text { communion in the Holy Trinity and in } \\
\text { the Sacraments. This unity is expressed } \\
\text { through the apostolic succession and } \\
\text { the patristic tradition and is lived out in } \\
\text { the Church up to the present day. The } \\
\begin{array}{l}\text { Orthodox Church has the mission and } \\
\text { tuty to transmit and preach all the truth } \\
\text { possible of the whole ecclesiological } \\
\text { question, and especially of their more } \\
\text { general teachings on sacraments, grace, } \\
\text { priesthood, and apostolic succession }\end{array} \\
\begin{array}{l}\text { Tradition, which also bestows upon the } \\
\text { Church her catholic character. }\end{array}\end{array}$ \\
\hline
\end{tabular}

${ }^{57}$ G. Vlantis, "Das Heilige und Große Konzil”, p. 9.

${ }^{58}$ Dietmar Schon, Die orthodoxen Kirchen im intereligiösen Dialog mit dem Islam, Berlin, Walter de Gruyter 2017, p. 496.

${ }^{59}$ See: The Encyclical of the Holy and Great Council of the Orthodox Church on: https://www. holycouncil.org/-/encyclical-holy-council, viewed on April 30, 2020.

${ }^{60}$ G. Vlantis, "Das Heilige und Große Konzil", p. 9.

${ }^{61} 2^{\text {nd }}$ paragraph of the: Relations of the Orthodox Church with the rest of the Christian World, https://www.holycouncil.org/-/rest-of-christian-world, viewed on April 30, 2020. 


\section{The Denial of the World Council of Churches as a Super-Church}

The denial of the branches theory by the Document on ecumenical relations as an ecclesiological option was once again obvious considering the approach towards the World Council of Churches (WCC). This institution was very important for the Orthodox ecumenical approach of that time, because in 1986, when the Document on Ecumenical Relations was under debate, all the Orthodox Autocephalous Churches were part of the WCC, so a common statement was needed. In 1986, the members attending the Third Panorthodox Pre-conciliar Conference wanted a document entirely dedicated to the question and status of WCC, which actually underlines the same ecclesiological question: what ecclesial status must the WCC have or not have?

In the sixth ${ }^{62}$ paragraph of the project (2015) of the Document on World Council of Churches was stated that: "WCC is not and must never become a super-Church". ${ }^{63}$

This statement reveals clearly the fact the Document on Ecumenical Relations was trying to be consistent with the other Ecumenical Document of 1986 and to reject the branches ecclesiology. It was very important to underline that the unity created among the different Christian Confessions by the common attendance in the WCC is not an ecclesial ontological union, but a common seeking of a Christian unity. This is why, according to some theologians the Document on Ecumenical Relations, suggests "a clear difference between the unity of the Church based on the characteristics above mentioned and the Christian unity, which was lost at some point in the history" ${ }^{64}$ But this fact does not affect the interpretation we suggested previously at all: an ecclesiological reception at different levels. What has always been rejected, even regarding the WCC, was the branches ecclesiology; this is confirmed by the intention of a Serbian Orthodox Metropolitan ${ }^{65}$ to enforce the exclusive ecclesiology and to eradicate any chance that WCC could ever be understood as a super-Church containing an ontological multi-confessional ecclesial unity. He proposed in 1986 to change the formulation "The WCC must not" with "can never become a super-Church".

\footnotetext{
${ }^{62}$ When this Document was merged with the other Document on Eumenical Relations in 2015, this paragraph regarding the WCC became the $19^{\text {th }}$ paragraph of the new united document.

${ }^{63}$ See: Synodica X, p. 135-136. English translation according to V. Ioniță, Towards the Holy and Great Synod, p. 169.

${ }^{64}$ See: Cristian Sonea, "The Ecumenical Dialogue according to the Holy and Great Council of the Orthodox Church in Crete (2016)", in: Roczniki Theologiczne 7 (2017), p. 130.

${ }^{65}$ Metropolitan Savva of Sumadija, part of the Serbian Orthodox delegation at the Third Panorthodox Pre-conciliar Conference.
} 
Ecclesiological Tendencies

\begin{tabular}{|l|l|l|}
\hline $\begin{array}{l}\text { The Document proposed } \\
\text { in the III }{ }^{\text {Id }} \text { Conference in } \\
1986\end{array}$ & $\begin{array}{l}\text { Proposal of Metropolitan } \\
\text { Savva in 1986 }\end{array}$ & $\begin{array}{l}\text { Final form approved in } \\
\text { Crete in } 2016\end{array}$ \\
\hline $\begin{array}{l}\text { WCC is not and must } \\
\text { never become a super- } \\
\text { Church }\end{array}$ & $\begin{array}{l}\text { WCC is not and can } \\
\text { never become a super- } \\
\text { Church }^{66}\end{array}$ & $\begin{array}{l}\text { It is therefore very clear } \\
\text { that the WCC does not } \\
\text { by any means constitute a } \\
\text { super-Church }\end{array}$ \\
\hline
\end{tabular}

In the united approved final document on ecumenical relations this paragraph was rephrased but the ecclesiological nuance remained the same: the rejection of the branches ecclesiology. In a very interesting way, this part of the newly united document on the ecumenical relations is consistent in mentioning theological and ecclesiological elements necessary in order for an ecumenical dialogue to be possible. Aspects such as faith in Jesus Christ, Trinitarian confession or sacraments ${ }^{68}$ are mentioned, opening the sense of the phrases regarding the WCC to the same possible interpretation of an ecumenical dialogue and a reception at different levels, or in the spirit of a total exclusive ecclesiology, but not at all to branches theory.

\section{Conclusions: One, Two or Three Competitive Ecclesiological Ten- dencies?}

Is there an ecumenical legacy left for future generations by the Council of Crete? Certainly yes, but not a clear and obvious one. Did the Council confirm a clear ecclesiological status for other Churches and Confessions? Clearly not, but according to Vlantis "the other Churches and Confessions didn't expect such a gesture". ${ }^{69}$ Dagmar Heller, a Protestant theologian, who very clearly understood that the main addressee of the document is the "Orthodox reader" ${ }^{\text {" } 0}$ underlines the lack of clarity ${ }^{71}$ of the ecumenical approach. Maybe this lack of clarity came from the complicated history of the text or/and because of the vast diversity of the Crete Council's legacy.

\footnotetext{
${ }^{66}$ V. Ioniță, Towards the Holy and Great Synod, p. 169.

${ }^{67}$ See the English version of the final approved document: Relations of the Orthodox Church with the Rest of the Christian World, available on https://www.holycouncil.org/-/rest-of-christian-world, viewed on April 30, 2020.

${ }^{68}$ Theological notions mentioned also in the second and in the sixth paragrapfs of the final Document.

${ }^{69}$ G. Vlantis, "Das Heilige und Große Konzil”, p. 9.

${ }^{70}$ Nonetheless, the ecumenical approach of the Council of Crete was attentively followed by the non-Orthodox world.

${ }^{71}$ D. Heller, "The (Holy and Great) Council", p. 298. He mentions also that when it comes to the inter-confessional marriages the ecumenical approach is even more unclear.
} 
The vast diversity of present and future readers which had to be approached with "pastoral care" led to the effect that the Document on Ecumenical Relations "tried to accommodate two competitive ecclesiologies" ${ }^{72}$ Bordeianu admits the possibility of interpretation of the Document in the key of two ecclesiologies: an exclusive one - Unam Sanctam and another one "to differing degrees, as also part of the Church". ${ }^{73}$ He does not mention at all the branches ecclesiology nor does it emerge into the "reception at different levels". But the protesters of the ecumenical approach of the Crete Council described the texts as branches ecclesiology, not of a "differing degrees" reception. Hierotheos Vlachos, ${ }^{74}$ who participated in the Crete Council, later described the document and the whole Council of being dominated by the "ecclesiology of the branches, baptismal theology and especially the principle of inclusiveness" ${ }^{75}$ Another notable critic of the document was well-known theologian and priest Theodore Zizis who even ceased the eucharistic communion with his bishop by refusing to mention his name during the liturgical celebration because his bishop signed the document on Ecumenical Relations in Crete. From the letter Zizis sent to his bishop to inform him about breaking the communion, one can understand the basis of his motivation: the same inclusive ecclesiology of branches. ${ }^{76}$

We followed the red thread of the ecclesiological development during the drafting of the document on ecumenical relations and we quoted notable historians of the Council that tried to defend the presence of the traditional Unam Sanctam ecclesiology in the Document on Ecumenical Relations such as: Metropolitan Job Ghetcha or Răzvan Perșa, or, important voices in ecumenism that observed the lack of clarity and sometimes, opposing ideas or theological statements. ${ }^{77}$ On one hand there was a fear that the most traditional

\footnotetext{
${ }^{72}$ R. Bordeianu, "Getting from Conflict to Communion”, p. 522.

${ }^{73}$ Ibidem. Radu Bordeian wites about this eccelsiology in same place: "This inclusivist ecclesiology is reflected in the pre-conciliar drafts, the views of the majority of participating bishops, most of the Orthodox faithful and representative theologians".

${ }^{74}$ Hierotheos Vlachos, Metropolitan of Nafpaktos and Hagios Vlasios is a member of the Church of Greece well known for his conservative theological views and for being contester of the Holy and Great Council.

75 See: Hierotheos Vlachos, "Intervention and Text in the Hierarchy of the Church of Greece (November 2016) regarding the Cretan Council", available on: https://orthodoxethos.com/ post/intervention-and-text-in-the-hierarchy-of-the-church-of-greece-november-2016-regarding-the-cretan-council, viewed on March 21, 2020.

76 "...we condemn the pan-heresy of Ecumenism and reject the pseudo-council of Crete, which has recognized heresies as churches, and affirmed syncretistic and destructive Ecumenism"; see the Letter of Theodoros Zizis (in English): http://orthochristian. com/103343.html, viewed on March 21, 2020. For a detailed and critical view on Thedoros Zizis actions against the Council, see: R. Perșa, “A canonical Analysis”, p. 150-151.

77 See: R. Bordeianu, "Getting from Conflict to Communion”, p. 524.
} 
circles will receive only a document containing an exclusive ecclesiology, but on the other hand, "this ecclesiology represents the root cause of Crete's hesitance of referring to Western Christians as churches"78 and no positive ecumenical reference could have been made according to this way of thinking.

A solution, both for traditional circles who renounce the inclusive theory of branches and for theologians who find the Document unclear, would be taking into consideration differing levels of reception. A reception of other Christian realities at differing levels is an understanding found in the Patristic heritage or even in modern Orthodox Theology, as we mentioned.

The same ecclesiological approach of a reception at differing levels was promoted both through the Decree on Ecumenism of the Second Vatican Council Unitatis redintegratio, the dogmatic Constitution on the Church Lumen Gentium and through the Declaration Dominus Jesus. In all these documents a clear difference is made between the Roman Catholic Church in which the Church "subsistit in" and Churches. Through "this realistic and humbled view (...), the Council with the words subsistit in allows not only for elements of the Church outside of its visible boundaries but also for sinful members and sinful structures within the Church itself" ${ }^{79}$ Cardinal Walter Kasper rejects the confusions between this Second Vatican Council ecclesiology and the theory of branches, writing that "it is a misunderstanding of "subsistit in" to make it the basis of an ecclesiological pluralism or relativism which implies that the one Church of Christ Jesus subsists in many churches, and thus the Catholic Church is merely one among many other churches". ${ }^{80}$ With regard to the Council of Crete the most common question among non-Orthodox is: "Was the Council for the Orthodox Church as the Second Vatican Council was for the Catholic Church?”. The answer could be both yes and no. Pietro Chiranz finds the resemblance in the relation Church - World, but also in the relation Orthodox Church - other Christian Realities proposed by the Holy and Great Council of the Orthodox Church. ${ }^{81}$ We could be encouraged then to ask also: Could the ecclesiological pattern of the Second Vatican Council be applied to the document on ecumenical relations of the Council of Crete? Our study highlighted that some of the theologians who attended the preparative process had precisely this ecclesiology (differing levels of reception) in mind.

\footnotetext{
${ }^{78}$ Ibidem, p. 522.

${ }^{79}$ Walter Kasper, "Lasting significance and urgency of Unitatis redintegratio", http://www. vatican.va/roman_curia/pontifical_councils/chrstuni/card-kasper docs/rc_pc_chrstuni_ doc_20041111_kasper-ecumenism_en.html, viewed on February 23, 2020.

${ }^{80}$ Ibidem.

${ }^{81}$ P. Chiaranz, La contestazione ignorata, p. 4.
} 
In the coming years, the reception of the Council will be decisive and finding a correct ecclesiological approach capable of uniting the "diversity" of the Orthodox readers is essential in order for this Council to be more than just a historical event. This ecclesiological uniting approach could or could not be the ecclesiological reception at differing levels, but for sure it will not be the branches ecclesiology, which is not found in the Council of Crete documents. Both the Second Vatican Council and the Holy and Great Council of the Orthodox Church rejected in their documents on ecumenism the branches theory, nonetheless both Councils were accused of promoting this ecclesiology because their members courageously questioned if the Christians found outside the official limits and ecclesial administration of their respective Churches "do not hold something of the Church?". The unjust rejection of Crete based on the branches ecclesiology is reflective of the heavy phrase pronounced by Monsignor Marcel Lefebvre: "J'accuse le Concile!”82

${ }^{82}$ Idea taken from Pietro Chiaranz; see: Ibidem, p. 6. 